\title{
Re-Inculturation of Pashtunwali and Afghaniyat in Naheed Hasnat Senzai's Shooting Kabul
}

\author{
Adnan Riaz \\ PhD Scholar, Graduate School of Social \\ Sciences, Atilim University Ankara, Turkey
}

\section{Abstract}

The paper analyses the immigrants' perspective on their homeland and tradition while living in a host culture as an immigrant in the novel Shooting Kabul. By focusing on Afghaniyat, the article underlines the critical aspects of Afghan culture incorporated by Senzai in this work and the re-inculturation of Pashtunwali and Afghaniyat in the immigrant communities. The argument builds on Mir Hekmatullah Sadat's concept of Afghaniyat and regurgitates that immigrants are reluctant to surrender their cultural norms outside their homelands. Practising Afghaniyat is challenging, demanding and continuous adherence to the subverting strife between the host majority society and minority Afghans. For the mentioned purpose, the text paper focuses on text analysis, giving references to culturally significant points and provides a view on immigrant feelings portrayed by the author. The study refers to the multiple historically significant codes of Afghaniyat, which combine the entire Afghan immigrant community into an Afghan nation outside Afghanistan.

Keywords: Afghan, Afghaniyat, immigrant literature, Pashtunwali, Senzai, Shooting Kabul

\section{Introduction}

Naheed Hasnat Senzai's Shooting Kabul (2010) is an immigrant novel echoing the formation, journey, stereotyping, and identity crises of Afghan migrants. Senzai's work Shooting Kabul depicts the circumstances of an immigrant family dealing with the anguishes related to Mariam, lost in the migration process. They left her behind while they are escaping Afghanistan and the Afghan Taliban. Shooting Kabul explores the complicated interaction of displacement, cultural grief, cultural heritage, and societal shift that immigrant groups face. Fadi is the male child of the family who accuses himself of leaving her sister's hand when boarding a truck; hence, Shooting Kabul is more than Mariam's narrative; it is Fadi's battle to bring his sister to the United States. The tale revolves around Fadi's fears and struggles in the aftermath of his sister's disappearance, and it depicts the terrible experiences of a young child. By 
focusing on the text, the article analyses the Afghan cultural identity encompassing the concept of Afghaniyat or Afghan-ness. Afghaniyat is a comprehensive phenomenon that incorporates Afghans' sociocultural fabric and advocates the idea of sticking to Afghan cultural values. The article approaches Afghaniyat as a part and parcel of immigrant life, playing a key role in community development and identity regeneration. It is the cultural energy that leads the immigrants to constant strife in the host society. Immigrants identify themselves as Afghans, suggesting that they do not appreciate the idea of Afghans being associated with Islamic terrorism. The significant aspects of Afghaniyat, such as the shelter of a guest escaping death, faith in God, hospitality, fearlessness, justice, loyalty, righteousness, and self-honour, are intrinsic parts of Afghan life. The article focuses on Senzai's adherence to the mentioned characteristics in the novel Shooting Kabul. Introduction to Shooting Kabul and Theoretical framework will precede the discussion.

\section{Theoretical Framework}

Mir Hekmatullah Sadat 2001 in the paper "The Quest for Afghanistan by Defining Afghaniyat" mentioned the word Afghaniyat (qtd in Hyphenating Afghaniyat 341). Sadat (2008) further discusses the concept in the paper "Hyphenating Afghaniyat (Afghan-ness) in the Afghan Diaspora" arguing that immigrant Afghans are culturally committed descendants' of the land called Watan and it also relates to their life while living in the host culture as an immigrant. Therefore, the Afghan Diaspora is thus approached through the prism of Afghaniyat. Afghaniyat includes Akhlaq-e wejdani, the aqa-id (beliefs), and Ananat (customs), which shape the mentality and way of life of Afghans. The feeling of the Afghan Diaspora's Afghaniyat maintains and influences its connections with the Afghans (homeland). Afghaniyat is therefore the means to assess its involvement and loyalty to the Afghan culture. In addition, the Afghan Diaspora assists Afghans in the Diaspora as cultural representatives for Afghanistan. Whereas culture and intercultural links are the reality of living in a globalized society, Afghaniyat becomes vital for the Afghan Diaspora's worldwide scattered populations. The Afghans have the choice inside the Diaspora to preserve, hyphenate or reject their Afghaniyat. More or less, Afghaniyat or Pashtunwali is the core of Afghan culture which is a sine qua non for the Pukhtun identity. according to Banting Errin (2003), it is the traditional lifestyle of the Pashtun people and Scholars widely have interpreted it as being "the way of the Afghans" or "the code of life" (p. 14). Although, as Singh (2014) argues that many academics have claimed that Pashtunwali spotlights Islamic principles, the code stretches back to pre-Islamic times. Hawkins (2009) sums Pashtunwali in "The Pashtun Cultural Code: Pashtunwali": Pashtunwali is a set of rules that govern how a Pashtun should live and how the tribe behaves and offer rules for acceptable Pashtun behaviour.

Wafamal (2014) summarizes the nuances of Afghan cultural segments known as Pashtunwali or Afghaniyat: Afghans believe that Pashtunwali could contribute to the transformation of the region's violent society into a peaceful one. Pushtunwali's 
fundamental components are Nanawatia (asylum), Isteqamat (trust in God), Melmastia (hospitality), Toorah (bravery), Badal (justice), Subt (loyalty), Imandari (righteousness), Ghayrat (self-honour) and so on. Within the context of Pashtunwali, deras, jirgas, and Loya jirgas are unique institutions that aid in the resolution of conflicts within the Afghan community and family. The Author holds that Jihaad and the culture of suicide bombing are foreign to Pashtunwali; in the refugee camps, these radical foreign philosophies were taught. Wafamal claims that Afghans' true culture is non-violent. Pashtunwali, according to the author, can assist the country to achieve peace and stability after 2014 .

\section{Discussion}

In Shooting Kabul, the Afghan immigrant community obeys the codes of Afghaniyat. Developing from the feelings of fear and anxiety, the immigrants endeavour to develop a replica of Afghanistan out of Afghanistan. Also, the continuous readjustment to the host culture reverberates a feeling of being distinct from their hosts. Jawad (1992) in Afghanistan: A Nation of Minorities regards Afghans as a diverse nation consisting of the tribe and ethnic groups, spread on the dispersedly populated Afghan soil. On similar grounds, in Shooting Kabul human life is portrayed as a reflection of culture facing a capitalist environment and its multiculturalism.

Fadi associates his sister's missing with the concept of womens' dignity known as namus in Afghan society. Fadi is the central character affected by the continuous pangs of namus. A Pashtun must "safeguard the namus with his life" (p. 13), and since his father Habib fails to defend his namus, his daughter therefore he squanders his sense of dignity. But it wasn't his fault only, Fadi believes since Mariam belonged to him too and "he has no respect" (p. 51) because Mariam was not protected by him. The dignity of women prescribed by the Afghan culture; is highly valued under the pretext of ghaiyrat which may roughly be described as an honour. In an article, the writer mentions that often the Afghan women cannot leave their homes without a male accompanying them (Safi, 2014). The gendered namus, which undertakes to protect the women is a degradation of the female gender which needs protection by powerful men. Men are belligerent, strong, committed and loyal to culture and the women are soft, docile and a commodified version of culture who are only valued to be protected. Senzai comments that many women traditionally wear a burka in Afghanistan, they are covered head-toe. However, most of them were forced to cover themselves. Even when asylum seekers are fleeing Afghanistan, they are covered in burkha. Gulmina, Mariam's doll also "wears a burka"( p. 25). The author presents an analogical standpoint referring to women and dolls wrapped in a burka. Interestingly, the influence of namus on life in Afghanistan is different from the Afghan's life in the immigrant communities living in the USA. In Shooting Kabul Noor finds opportunities to work and help her family financially in the USA while in Afghanistan she was wrapped in a burka, living as an inactive member of the society. Noor helps Fadi and her family with money. Marta Tienda \& Ron Haskins in "Immigrant Children: 
Introducing the Issue" that though the "immigrants are not paid well compared to hosts' children," (p. 15) Noor retains a significant status in the Afghan family structure because of her financial output. She subverts the concept of Afghaniyat in the host culture. The entire cultural operation is changed by access to education and economic possibilities. Afghan migrants are introduced to a different lifestyle which might influence schooling, active involvement in society and marriage of the girls. Noor's character will develop into a distinct Afghan character, different from her mother and familial cultural background. The novel creates another realm for approaching Afghaniyat based on the economy playing a key role in shifting Afghan cultural tendencies. Like any other culture, the financial condition of the Afghan family helps them develop a new way of seeing life in the host culture.

Independence of land is also an essential element of namus and those fighting to safeguard it are the cultural heroes. In the article "Being Pashtun-being Muslim: Concepts of Person and War in Afghanistan," the author Bernt Glatzer (1998) explains the notion of namus means "Afghan country to be safeguarded against aggression" (p. 4 ); it is a cultural retaliation against the invader. The author describes the Afghan enigma saying that because of the geography of Afghanistan, the land is invaded by foreign forces. The Afghans have learnt to defend their homeland against the tyranny of oppressors. Maley (2009) sums up Afghanistan's socio-political condition; it has seen decades of peace and long spells of wars. For more than half the 20th century, from 1929 to 1978, it was among the most peaceful Asian nations. It upheld its impartiality during the Second World War, prevented conflicts with its neighbours, and escaped widespread slaughter and chaos on its land. All this started to disintegrate after the Communist revolution of 1978. This is also an imperative gesture to justify the aggressiveness and harshness of the culture as represented in the novel.

The Afghans proudly declare themselves as Afghans first, then Muslim which suggests that they do not regard the concept of Afghans' associated with Islamic terrorism. Borthakur \& Kotokey (2020) argue that the conflict in Afghanistan is apparently fueled by the jihadi mindset but is equally supported by Pashtun nationalism. Their stay in the USA gives them freedom from aggressiveness in Afghanistan. Fadi's father believes that the Taliban have overrun Afghan soil, creating havoc killing millions of people belonging to all ethnicities (p. 230). Since the Taliban are vehemently supported by the Pukhtun majority mujahideen, the rest of the ethnicities have to go through their maltreatment. Senzai develops an Afghan perspective indifferent to rifts in the concepts of Islamic terrorism and Pukhtun majority support of jihad. On contrary, Senzai declares Osama, an Arab, as Riedel (2008) mentions that Osama was a "wealthy Arab" (p. 34). The author reflects partiality and creates a rift in the concept of Afghaniyat by mentioning Pukhtun and Farsi speakers as distinctive ethnicities; they are described as the Northern Alliance commanded by General Ahmed Shah Masood during the Soviet conflict; it was comprised of the Farsi-speaking nonPukhtun communities. Some people did not agree and were "led by crooked, 
oppressive warriors" (p. 48). More than the Islamic colours, the post 9/11 political paradigm shift forces the Afghans to camouflage in the Afghan shades. The Afghan children fear alienation at schools and therefore, unequivocally declare themselves Afghans and believe that it is the time to muster up strength by standing together. Afghan elders also shed off their ethnic identities of Tajiks, Uzbeks and Pashtuns and declared to bury their ethnic hatchets come "together as Afghans, for the sake of their country" (p.177).

Relatives, family friends and guests are deemed as blessings in Afghaniyat. In Shooting Kabul, the author refers to Fadi's extensive Khanawada (family)associations. Aunts, uncles and distant relatives are in constant touch with Habib and his family while they are facing the trauma of Mariam loss during the escape. Afghans value the display of sympathy and care for the ones in grief; it is extended as a social phenomenon wherein the people are bound to help each other both morally and materially. When Fadi's father decides to leave his house, Uncle Amin is furious as he mutters that he is offended when Fadi's family leaves his house. However, Shooting Kabul raises the concern that if immigrants are unable to retain certain aspects of authentic Afghan culture, they may forfeit their heritage while residing in foreign societies that value cultural identity and welcome heterogeneity. Also, Westernized Pashtun may restructure their families. The worry expressed in Shooting Kabul is that if immigrants are unable to retain certain aspects of authentic Afghan culture, they may lose their heritage while living in host cultures that value cultural heritage and welcome variety. According to Khayyam et.al in "Socio-cultural dynamics and their relation with the participatory development in the Pashtun tribal society of Pakistan" Melmestia is a collection of rules and an instant reward from society for upholding local cultural norms, which extends to the offer of refuge (panah) if threatened or sought willingly. The responsibility of a visitor to respect the host is at the heart of hospitability. Osama bin Laden is protected against the USA since Afghans have a considerate view of Nanawatia or Panah (seeking refuge); which means the protection of one's guests at any cost, against an enemy or opponent. Osama's panah costs the Afghans thousands of lives, and the Afghans proudly mention it as a Pashtun cultural code: "Taliban have offered "Osama Panah, so he is not leaving Afghanistan" (p. 175). If a person requests to Afghans for protection from his adversaries, according to the Pashtunwali code of panah, that person, in this case, Osama bin Laden, was sheltered.

Afghaniyat is differently received by different age groups in the USA. Natalie observes that an immigrant character is more interested in maintaining his or her dual personality than in abandoning the comforts of home and diving headfirst into the process of assimilating into the social culture. Children have heard of the Afghan nationality in idealistically perceived clothing and at the same time, they face stereotyping in their day to lives. Fadi is left at the crossroads when the white children call him Osama bin Laden, associating Afghans with modern terrorism. Therefore, the youngsters form a community within the Afghan community and yearn to take 
revenge, called Badal in Afghaniyat. Badal is also a form of justice that the Afghan children decide to take on for Fadi. Shah et.al (2008) in the article "Jihad or Revenge: Theorizing Radicalization in Pashtun Tribal Belt along the Border of Afghanistan" opine that vengeance is seen as an inherent element of the tribal code of life, it is recognized as having the same legal force as any other laws. He further adds that the conflict in Afghanistan has become "a sort of revenge" (p. 74). Similarly, it appears as if Fadi is trying to revenge on the white community as a whole because of the ongoing bombings on Afghan soil by the NATO forces. The author mentions that:

Tomahawk cruise missiles were launched from both US and British ships this evening, signaling the start of Operation Enduring Freedom. This was accompanied by a mix of strikes from land-based B-1 Lancer, B-2 Spirit, and B-52 Stratofortress bombers. The initial military objective, as articulated by President George W. Bush, is to destroy terrorist training camps and infrastructure within Afghanistan, the capture of alQaeda leaders, and the cessation of terrorist activities. (p.237)

Toorah (bravery) is an integral part of the Afghan social fabric. Young Afghans use Chaapa (guerrilla tactic) technique to stand against the white strength; they historically associated it with the Afghans fighting invaders. It is a form of warfare based on guerrilla techniques, a kind of unconventional warfare through which small clusters of fighters, such as militias, armed civilians or irregulars, utilize military techniques to resist a greater, more dynamic conventional army, involving ambush, destruction, assaults, minor warfare. Fadi's cultural adherence multiplies under the current circumstances; they revere Afghan culture more than would have cherished it in Afghanistan, considering the situation there. Eisenbruch (1991) elaborates the gloomy thinking and rage that interferes with the everyday existence of children on foreign soil force them to reimagine their past. Dr Graham \& H. Turbiville, Jr, (1985) in "Ambush! The Road War in Afghanistan" mention in the Afghan-Soviet War, ambush tactics against the Soviets were described as an effective strategy for seizing weapons and ammunition.

Afghans slightly shed off Pashtunwali when they connect with the majority host society. It is because they neither face those challenges which they would normally face in Afghanistan, and they also have a depowered status in the USA. It exposes the characters to the so-called more civilized western society wherein they cannot enjoy the freedom of practising their tribal culture. At the outset of the exposure to the new society, Fadi curses himself for his inability to protect his namus which is placed in Mariam; and says "It's me that has no honour" (p. 107). Throughout his excessive selfindulgent period, he believes that he has no worth because of the crime he has committed. However, his character softens over time and starts to miss Mariam as a sister, not his valued dignity. Fadi treats his sister Noor through the glasses of US conception of sister. Fadi unrestricted submission to new norms introduces a more sophisticated way of seeing Afghaniyat. Bhugra (2004), in his article "Migration, Distress and Cultural Identity," says that minorities have to be involved 
unintentionally with most of the community to avoid persecution, which will provide the women of these families more opportunities.

\section{Conclusion}

Shooting Kabul summarizes the core ideals of Afghaniyat and Pashtunwali. In the USA, immigrants create a cultural image of their Afghan life and its memories. The author not only formulates a view on the cultural sentiments, and adherence to codes, but she also constructs a social structure fundamental to their livelihood in the host conditions. They show a desire to abide by the codes of Pashtunwali; Afghans are mostly devout Muslim believers but they call themselves Afghans first and then Muslims. They reflect two aspects of namus: in Mariam's case and the sovereignty of Afghanistan. Other culturally distinctive features such as protection of guests, bravery, the dignity of family, justice and revenge have consideration in the novel. With Mariam's arrival to the USA, the reader may feel a slight shedding off the Afghan traditions but 9/11 revitalizes the cultural cracks and reinforces the cultural variances; it looks as if she is coming to her home after being lost in Afghanistan. The Afghans show the will to plan cultural hybridity, but it will take its natural course. For the future researchers, Shooting Kabul will provide ample evidence for reviewing Afghans' life in the host culture.

\section{References}

[1] Afghanistan: A nation of minorities: Report / by NASSIM JAWAD. (1992). https://doi.org/10.2458/azu_acku_pamphlet_ds354_5_j39_1992

[2] Bhugra, D. (2004). Migration, distress and cultural identity. British Medical Bulletin, 69(1), 129-141. https://doi.org/10.1093/bmb/ldh007

[3] Borthakur, A., \& Kotokey, A. (2020). Ethnicity or religion? The genesis of the Taliban movement in Afghanistan. Asian Affairs, 51(4), 817-837.

[4] Coulson, A. B., MacLaren, A. C., McKenzie, S., \& O'Gorman, K. D. (2014). Hospitality codes and social EXCHANGE theory: THE Pashtunwali and tourism in Afghanistan. Tourism Management, 45, 134-141. https://doi.org/10.1016/j.tourman.2014.03.019

[5] Eisenbruch, M. (1991). From post-traumatic stress disorder to Cultural BEREAVEMENT: Diagnosis of Southeast Asian refugees. Social Science \& Medicine, 33(6), 673-680. https://doi.org/10.1016/0277-9536(91)90021-4

[6] Friedman, N. (2008). From hybrids To Tourists: Children of immigrants in Jhumpa Lahiri'sthe Namesake. Critique: Studies in Contemporary Fiction, 50(1), 111-128. https://doi.org/10.3200/crit.50.1.111-128

[7] Glatzer, B. (1998). Being Pashtun--being Muslim: Concepts of person and war in Afghanistan. 
[8] Gupta, A. (2014). Beyond strategies: Cultural dynamics in Asian connections, by Priya Singh, Suchandana Chatterjee, Anita Sengupta and Arpita Basu Roy. Strategic Analysis, 38(4), 608-610. https://doi.org/10.1080/09700161.2014.918693

[9] Hawkins, J. (2009). The Pashtun cultural code: Pashtunwali. Australian Defence Force Journal, (180), 16-27.

[10] Khayyam, U., Inamullah, E., \& Shah, S. (2018). Socio-cultural dynamics and their relation with the participatory development in the Pashtun tribal society of Pakistan. Trames. Journal of the Humanities and Social Sciences, 22(2), 173. https://doi.org/10.3176/tr.2018.2.05

[11] Maley, W. (2021). The Afghanistan wars. MacMillan international higher education.

[12] Riedel, B., \& Saab, B. Y. (2008). Al Qaeda's Third Front: Saudi Arabia. Washington Quarterly, 31(2), 33-46

[13] Sadat, M. H. (2008). HyphenatingAfghaniyat(Afghan-ness) in the Afghan Diaspora. Journal of Muslim Minority Affairs, 28(3), 329-342. https://doi.org/10.1080/13602000802547898

[14] Safi, M. I., \& Ahmad, S. A. (2014). Honour killings in Afghanistan: Perspective of Sharia and law. International Islamic University.

[15] Senzai, N. H. (2011). Shooting Kabul. Simon \& Schuster Children's Pub.

[16] Shah, A. A., Ehsan, N., \& Malik, H. (2019). Jihad or REVENGE: Theorizing radicalization in the Pashtun tribal belt along the border of Afghanistan. Global Political Review, IV(II), 67-77. https://doi.org/10.31703/gpr.2019(ivii).07

[17] Tienda, M., \& Haskins, R. (2011). Immigrant children: Introducing the issue. The Future of Children, 21(1), 3-18. https://doi.org/10.1353/foc.2011.0010

[18] Turbiville Jr, G. H. (1985). Ambush! The road war in Afghanistan. Foreign Military Studies Office.

[19] Zalmay Wafamal. (2014). "Pashtunwali." Beyond Strategies: Cultural Dynamics in Asian Connections. Strategic Analysis, 38(4), 608-610. https://doi.org/10.1080/09700161.2014.918693 